\title{
A NEW ADDITION TO THE COSTA RICAN FLORA: PALMORCHIS NITIDA (ORCHIDACEAE: NEOTTIEAE) IS DOCUMENTED FROM THE OSA PENINSULA
}

\author{
Catherine V. Bainbridge ${ }^{1} \&$ Reinaldo Aguilar \\ Los Charcos de Osa - Center for Regional Plant Diversity, Osa Peninsula, \\ Apdo. \# 76-8203, Puerto Jimenez, Golfito, Costa Rica. \\ 'Author for correspondence: cbainbridge@osaresearch.org
}

\begin{abstract}
Palmorchis nitida, previously known from seasonally wet forests of Panama, is reported from the Osa Peninsula in south-west Costa Rica. Notes and figures are provided regarding its natural history and phenology. The variable nature of this species is discussed on the basis of recently collected Costa Rican material.

Resumen: Palmorchis nitida, hasta ahora conocida solamente de bosques húmedos estacionales de Panamá, se reporta como una especie nueva para la flora de Costa Rica. Se presenta nueva información sobre su historia natural y se discute la naturaleza variable de esta especie con base a los nuevos especímenes colectados en Costa Rica.
\end{abstract}

Key word / Palabras clave: Orchidaceae, Neottieae, Palmorchis, P. nitida, Costa Rica, Osa Peninsula, Panama.

After years of botanical sampling of the speciesrich forests of the Osa Peninsula, located in Costa Rica's south Pacific, one might assume that nothing new remained to be discovered. Just how wrong this is, can be clearly demonstrated by the fact that new registers and, indeed, new species, continue to issue from the region, including areas that have long served as choice collecting sites. One of the latest in a growing list of surprising plant discoveries to come out of the Osa Peninsula, is Palmorchis nitida Dressler (Orchidaceae: Neottieae).

Although a relatively small neotropical genus - 22 species are listed by the International Plant Names Index - as Dressler $(1983,1984)$ explains, spotting the genus in its natural environment and, subsequently, distinguishing between species, can be anything but a straightforward task, as plants look enough like palm seedlings or broad-leaved forest grasses that they are easily overlooked when not in flower. With the exception of $P$. powellii, which displays a much larger growth habit than that of any other species present in either Costa Rica or Panama, (reaching up to $1 \mathrm{~m}$ or more), members of this genus are similar both in habit and vegetative appearance. Even in the case of $P$. nitida, where the specific epithet refers to the brilliance of the leaves, older leaves can appear dull due to the presence of small mosses growing on their upper surface. Thus, we depend on the presence of flowers to make anything more than a generic determination. But, as plants in a population all flower on the same day, and flowers last only a few hours, one needs to monitor plants over an extended time period in order to find flowers.

Dressler was surprised to discover that plants growing by a well-used trail on Panama's Barro Colorado Island that he had taken to be $P$. powellii were a distinctive new species, $P$. nitida (Dressler $1983,1984)$. We were equally surprised to discover that plants we had taken to be $P$. silvicola L.O.Williams (1970) were P. nitida, a species from Panama.

We first observed plants on the Osa Peninsula in Costa Rica in November 2004, growing in secondary forest on the slopes of the property Los Charcos de Osa. However, it was not until July 2006, that we were lucky enough to finally observe, and photograph, the 

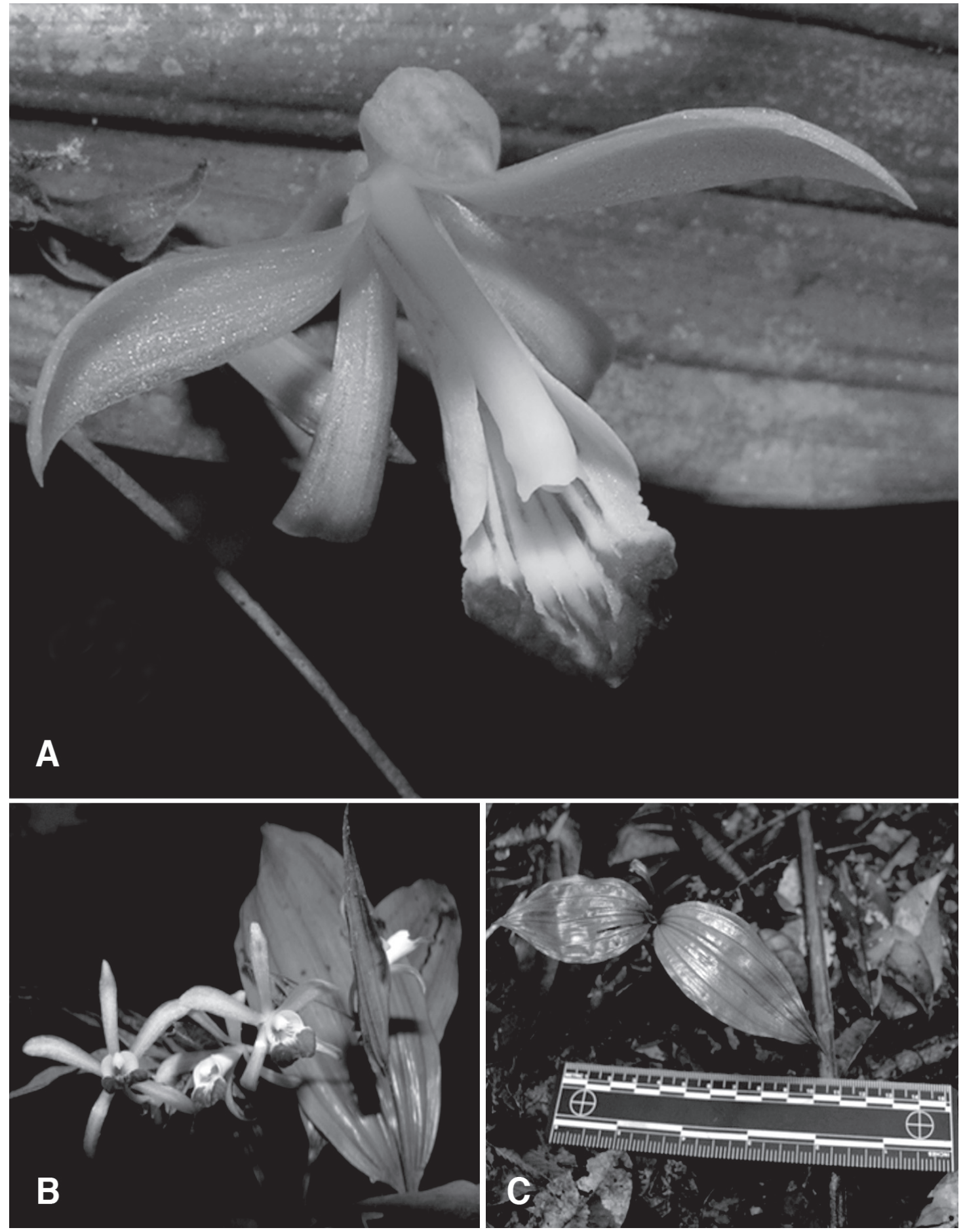

FIgURE 1. A - A single flower of P. nitida. B - Less commonly P. nitida produces several flowers simultaneously from more than one inflorescence. C - A juvenille plant amongst the leaf litter. Photographs by Reinaldo Aguilar, 2006. 
flowers of this species (Fig. 1). We then noted that our plants conformed with the description of $P$. nitida as presented in Dressler's (1993) dichotomous key and with an incomplete description from the Manual de Plantas de Costa Rica (Dressler, 2004) documented as Palmorchis Sp. B., which cites a collection made by Mike Grayum (Grayum et al. 4027, MO), as early as 1984. Probably, P. nitida is the "undescribed species in the south Pacific lowlands of Costa Rica" that Dressler (1997) referred to a decade ago.

The apparent leap in geographical distribution from eastern Panama to the relatively isolated south west coast of Costa Rica - is perhaps an indication that $P$. nitida will prove to have a more continuous distribution through central Panama and northwards along the Pacific slopes. Dressler $(1983,1984)$ faced a similar geographical disjunct when considering the possible existance of $P$. silvicola - originally described from the Osa Peninsula - in central Panama. We anticipate that many more principally Panamanian species are likely to show up on the Osa Peninsula in the future.

We report here the first record of $P$. nitida for the flora of Costa Rica on the basis of the following voucher:

Costa Rica. Puntarenas: Osa Peninsula, Canton de Osa, District of Sierpe, Finca Los Charcos de Osa, $1 \mathrm{~km}$ before the village of Banegas. 0840'18'N8330'17'W, 30 Nov 2006, C. $V$. Bainbridge 263 (USJ).

On the basis of fresh material from Costa Rica, we have observed that the species can be variable. The more typical form we have observed being compact plants, of up to $30 \mathrm{~cm}$ tall. Less commonly encountered, is the larger to more elongate form, superficially more related to $P$. trilobulata (i.e., as can be seen in $A$. Chacón 931, INB), with a terminal leaf lamina of $25 \mathrm{x}$ $8 \mathrm{~cm}$ and floral bracts which are well-spaced along the rachis (Fig. 2).

Prior to collection, two plants of $P$. nitida were monitored by us over a six month period and we recorded flowers opening on the following dates:

- Bainbridge 263, Example A: 23 Jul 2006, 13 Aug 2006, 27 Aug 2006, 17 Sept 2006, 20 Oct 2006, 18 Nov 2006.

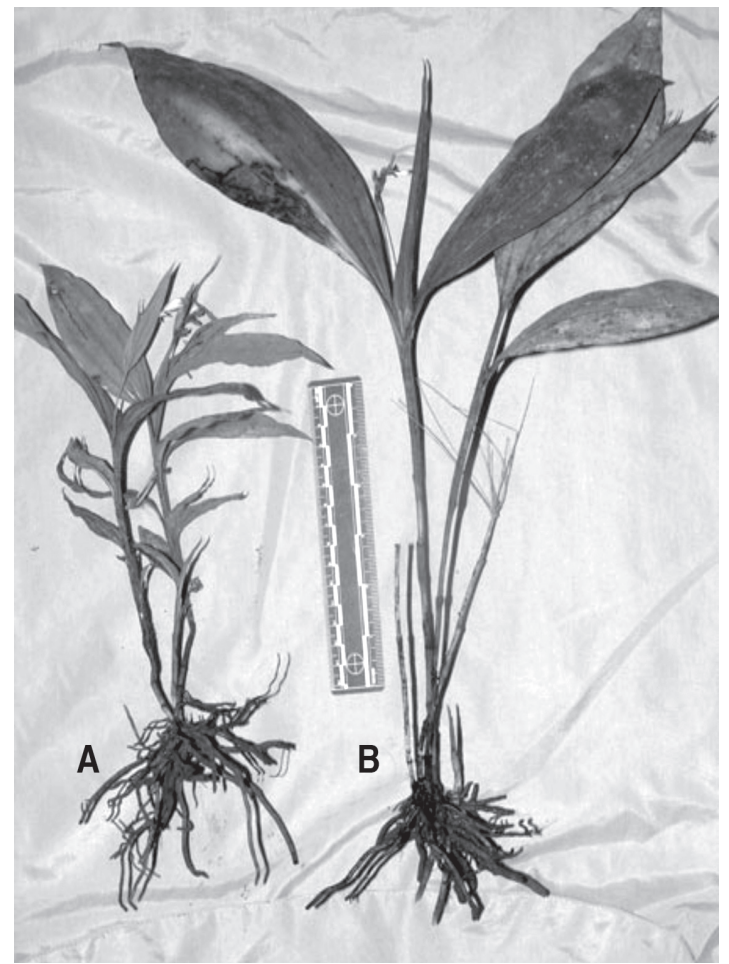

FIgURE 2. Variability in vegetative form in Costa Rican plants of $P$. nitida. A - The more common and compact form, similar to that of $P$. silvicola. B - The less common more elongated form, similar to that of P. trilobulata. Photograph by Reinaldo Aguilar. 2006.

- Bainbridge 263, Example B: 29 Jul. 2006, 7 Sept 2006, 21 Oct 2006, 29 Oct 2006, 21 Nov 2006.

Herbarium records show that flowers were produced in October (Grayum et al. 4027, MO) and in July (A. Chacón 931, INB) and buds were also recorded as present in wild individuals at Los Charcos on 27 Dec. 2006, 15 Feb. 2007, 15 Apr. 2007, and 15 May 2007. This information suggests that the species may have an extensive flowering period. A single mature fruit was collected on $20 \mathrm{Oct}$ 2006. Cited material has been preserved in an alcohol and glycerine mixture.

The following presents a brief list of associated plants encountered in the habitat of P. nitida on the Osa Peninsula: Cyclanthus bipartitus (Cyclanthaceae), Cryosophila guagara, Asterogyne martiana (Arecaceae), Heliconia irrasa, H. latispatha. H. imbricata (Heliconiaceae), Costus stenophyllus (Costaceae), 
Psychotria acuminata, P. elata (Rubiaceae), Calathea crotalifera (Marantaceae), Miconia nervosa, M. osaensis (Melastomataceae), Sarcoglottis hunteriana, Stenorrynchos lanceolatum, Oeceoclades maculata (Orchidaceae), Bauhinia bahiachalensis, B. guianensis, Peltogyne purpurea (Caesalpinaceae), Williamodendron glaucophyllum (Lauraceae), Couratari scott-mori, C. guanensis (Lecythidaceae), Newtonia suaveolens, Acacia alleni (Mimosaceae), Coccoloba standleyana (Polygonaceae), Sloanea sulcata (Elaeocarpaceae) and Chaunochiton kappleri (Olacaceae).

AcKNowledgments: Our thanks to Jorge Lobo, Luis Diego Goméz, Franco Pupulin and Robert L. Dressler for their valuable comments during the preparation of this manuscript.

\section{Literature Cited}

Dressler, R. L. 1983. Palmorchis in Panama mit einer neuen Art, Palmorchis nitida, an einem unerwarteten Standort. Orchidee 34(1): 25-31;

Dressler, R. L. 1984. Palmorchis in Panama: with a new species where least expected. Orquidea (Méx.) 9(2) May.

Dressler, R. L. 1993. Field Guide to the Orchids of Costa Rica and Panama. Cornell University. p.310.

Dressler, R. L. 1997. Orquideología; Revista de la Sociedad Colombiana de Orquideología 20(3): 263, f.

Dressler, R. L. 2004. Orchidaceae. In: B. Hammel, M. H. Grayum, C. Herrera \& N. Zamora (eds.). Manual de Plantas de Costa Rica. Missouri Botanical Garden Press. Vol: 3

Williams, L. O. 1970. Palmorchis silvicola, Fieldiana, Botany 32(12): 199.

International Plant Names Index (IPNI - http://www.ipni. org, electronic pages consulted $20^{\text {th }}$ March, 2008). 